Arch. histol. jap. Vol. 31, No. 2 (1969)

p. $155-166$

Department of Microbiology (Prof. T. Akisada) and Department of Oral Histology (Prof. H. SAEguSA), Kyushu Dental College, Kokura, Kitakyushu, Japan

\title{
Scanning Electron Microscopy of Developing Deciduous Tooth Enamel ${ }^{*}$
}

\author{
Junichi Tokunaga and Akitatsu Shimamura \\ (德永純一と島村昭辰)
}

(Received November 7, 1969)

The surface of human tooth enamel is characterized by numerous microscopic depressions that lie along the entire length of the perikymata and imbrication lines. Together with pits and fissures that are normally found on the occlusal surface of teeth and are allegedly responsible for the initiation of carious lesion, these microscopic depressions have been recognized as another important factor in studies of the prevention of carious lesions. Since the depressions apparently represent the final forms which developing enamel rods assume at the time of their completion, it is of significance to know how they appear in earlier stages of tooth development and what the true mechanism is of the formation of such depressions on the surface of mature enamel.

In view of the above considerations and based upon available information recently accumulated by means of both conventional and scanning electron microscopy, we have undertaken a preliminary study on the morphological changes of the depressions with the aid of a scanning electron microscope, using deciduous tooth germs as material. The study included morphological changes in the depressions of the rod ends from the immature to mature stages of enamel development, the arrangement of the rod end matrix complexes, the morphological details of organic granules lying along the walls of the depressions, descriptions of the form and orientation of crystal structures that were found in the enamel matrices, and surface analysis of $\mathrm{Ca}$ and $\mathrm{P}$ concentration in the immature surfaces of developing tooth enamel with an electron scanning probe X-ray microanalyser.

\section{Materials and Methods}

All the tooth germs from deciduous dentitions in the upper and lower jaws were excised from three human fetuses ranging in age from 6 to 8 months. These served as experimental material. The excised germs were fixed either in $2.5 \%$ glutaraldehyde solution or in a $10 \%$ neutral formalin-saline mixture, and cellular components were carefully scraped off the enamel surfaces. In a number of specimens selected from paired teeth on opposite sides of the jaw, treatment with 1:2 diamino-ethane was carried out to remove organic materials from the enamel surfaces after they had been freed of cellular components by mechanical scraping. After dehydration in acetone, the specimens were rapidly and gently dried with warm air. They were coated with carbon and gold in a vacuum evaporator and rotated during evaporation in order to ensure good coverage.

A JSM-2 scanning electron microscope and a JXA-5 electron probe scanning

\footnotetext{
* This study was partly supported by a Scientific Research Grant from the Japanese Ministry of Education.
} 
$\mathrm{X}$-ray microanalyser were used for this work.

\section{Observations and Discussion}

\section{Surface view of immature tooth enamel}

The surface of immature enamel appears to consist of a regular arrangement of depressions, each of which is concave due to the formation of the interrod portion which always preceded that of the rod ends. These depressions should be regarded, as suggested by Boyde (1967), as spaces that had been occupied by Tomes processes of ameloblasts, and hence reflect the functional contours of these cells at the time of enamel matrix formation. The size and depth of these depressions varied according to the stage of enamel development.

In immature stages of enamel development the depressions were always deeper than those seen in the mature enamel and showed either tapered cylindrical or wedgelike forms, the latter being somewhat predominant. Walls of the cuspal or lateral sides of the depressions reached the floor with a longer and gentler slope than did the remaining walls. The honeycombed septa or ridges that constituted the margins of each depression measured from 0.5 to $0.7 \mu$ and appeared generally hexagonal, with maximum diameter ranging from 5 to $7 \mu$. There were, however, a considerable number of deviations from the typical forms (Fig. 1).

The extent of regularity in the arrangement of such honeycombed depressions was more or less limited to small regions. These regions were separated by the presence of depressions, irregularly shaped and sometimes reduced in size, marking the boundaries between individual regions. On closer observation, however, it was revealed that even in such regions of apparent regularity no single pattern of arrangement was dominant throughout the area.

Although a majority of depressions were bound by intact hexagonal ridges of interrod portions separating one from the other, there were also some occasional sites where a side ridge of the hexagon was either defective or incompletely formed thus showing two or more depressions fused together as seen in Figure 2. This would seem to correspond to BoYDE's pattern 2 and 3 (1965) for the developmental patterns of tooth enamel. Particular attention should be paid to Figure 2. The fused appearance of the three depressions in this picture reminded us of BOYDE's opinion that the ameloblast could slide from one depression to another during formation of the mineralizing front and of ReITH's conclusion, to the same effect, that these cells were literally dancing back and forth between depressions. We have not as yet done any further study on this point.

In the interpretation of BoYDE's pattern 2 and 3, as proposed for the arrangement of depressions, we sometimes felt it difficult to distinguish one from the other because the segment under observation could appear either in pattern 2 or in pattern 3, depending on the manner in which the specimen was oriented for observation.

On the walls of the depressions there were numerous structures of varying size and form. Some took acicular to columnar forms and were apparently crystalline structures in their formative stages; they measured 0.5 to $1.0 \mu$ in length and 0.1 to $0.2 \mu$ in width. The rest consisted of slightly larger and longer cubic forms ranging in length from 1.0 to $2.0 \mu$ and in width from 0.3 to $0.5 \mu$. They were attached to the walls in clusters or separately in a random manner. The floor of the depressions were 
rough-surfaced, being covered by particles smaller than $100 \mathrm{~m} \mu$ in diameter (Fig. 1-C).

A
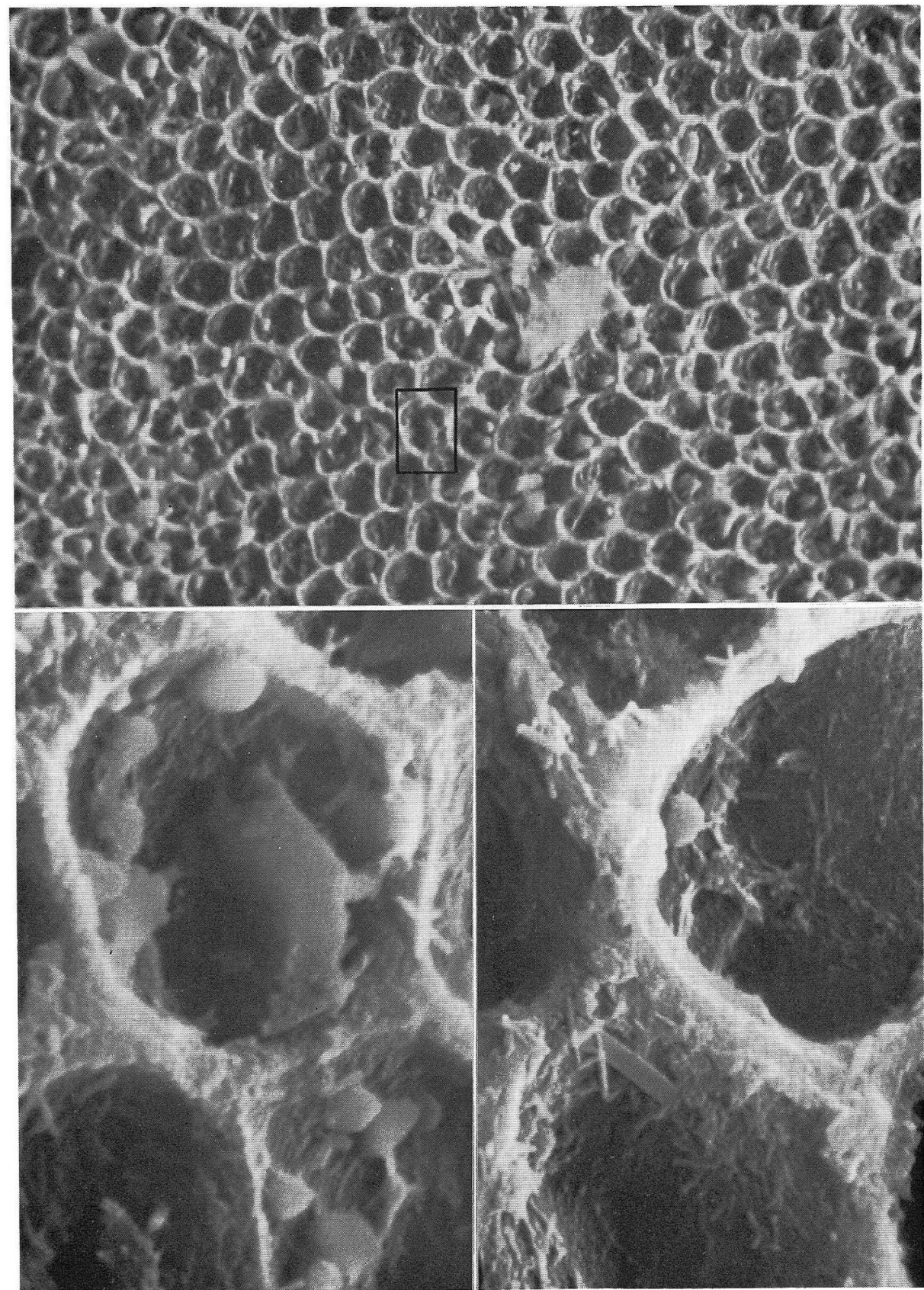

C

Fig. 1. The surface view of immature tooth enamel. A. A regular arrangement of deeper depressions showing honeycombed appearance. $\times 1,200$. B. A closer view of the marked area of Figure A showing spherical granules and amorphous lumps in the depressions. $\times 12,000$. C. Numerous structures of varying size and form attached to the walls of the depressions are seen. 


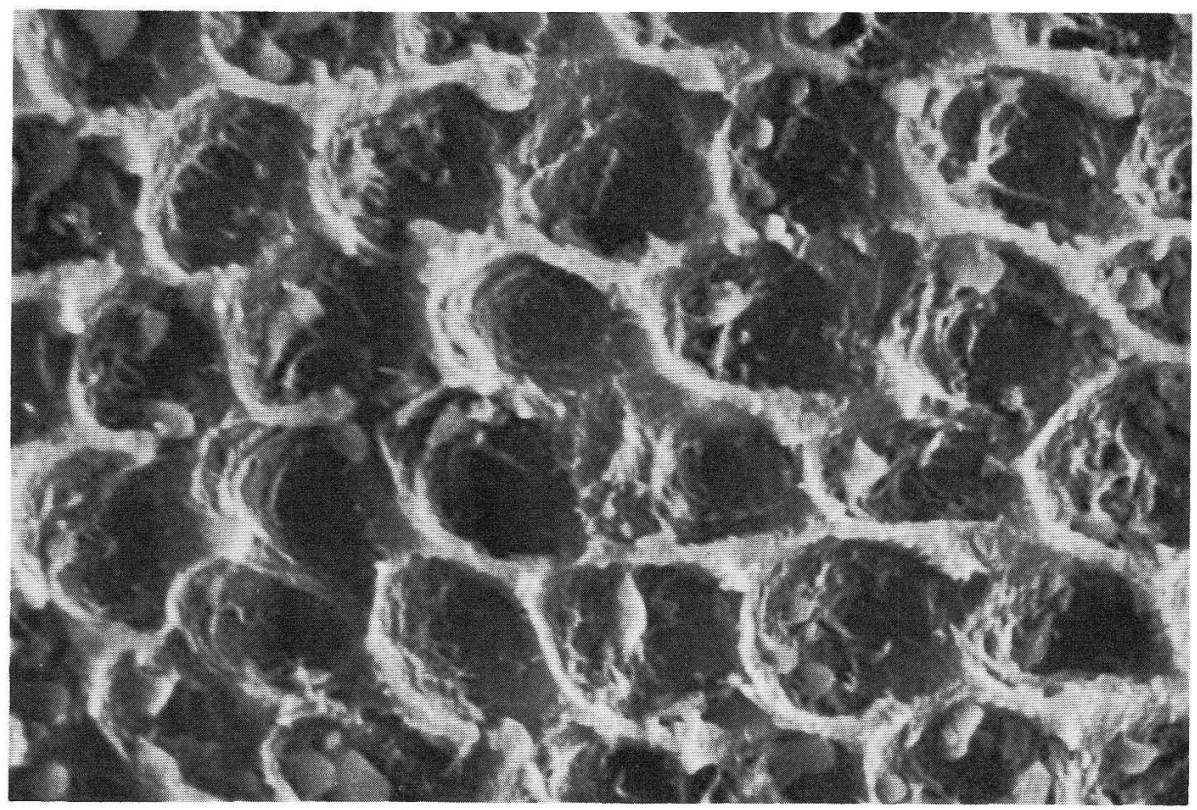

Fig. 2. Hexagonal ridges of the depression showing partial incomplete formation. $\times 3,600$

As shown in Figure 1-B, many depressions also contained other structures, such as spherical granules of about $1.0 \mu$ in diameter and amorphous lumps as large as 4 to $5 \mu$ in diameter. Some of these lumps appeared to be fusion products of the spherical granules, but the latter forms generally occurred singly or in pairs in some depressions and as assemblages of several granules in others. When viewed under higher magnification, these spheroids and lumps showed smooth surfaces and were sometimes laden with the acicular to columnar crystals described above. On the basis of our experiments with an organic solvent, to be described later in more detail, these spheroids and lumps were concluded to consist of organic substances. It should be added that these spheroidal forms are identical with those forms obtained by many investigators in studies using ultrathin sections which were referred to variously as amorphous large globules (Sognnaes et al., 1952), amorphous substances (NyLEN and ScOTt, 1960; Fearnhead, 1961; Rönnholm, 1962; Frank and Nalbandian, 1963) and extracellular granules (BoyDE, 1967). With regard to the origin of the amorphous-shaped lumps, we are not certain whether they might be a true fusion product of the spheroidal substance or a final form of residual Tomes process separated from the body of an ameloblast.

\section{Surface analysis of $\mathrm{Ca}$ and $\mathrm{P}$ concentration in immature tooth enamel with elec- tron probe scanning $X$-ray microanalyser}

The characteristic X-ray image of calcium $\mathrm{K} \alpha$ from the immature tooth enamel surface using the same materials under an electron probe scanning X-ray microanalyser is shown in Figure 3. In this view each depression, its surrounding hexagonal ridges and amorphous lumps (arrows of Fig. 3--B) appeared in contrast to one another; this finding suggested that the calcium concentration of the enamel rod ends was much 
higher than that of the interrod portions and amorphous lumps. This would suggest that the interrod portions represented enamel matrix secreted later than the enamel rod ends. On the other hand, there was no appreciable difference in phosphorus concentration in the same area studied.

A
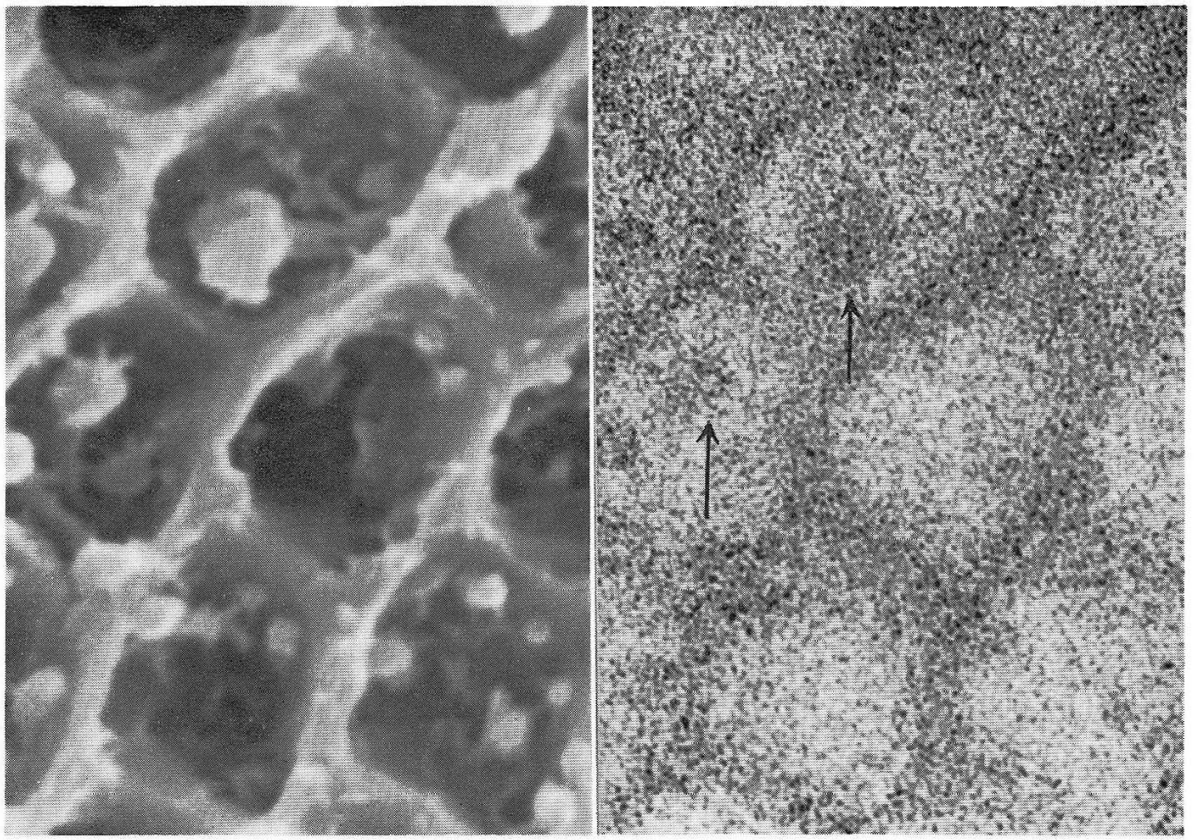

Fig. 3. The electron image by the electron probe X-ray microanalyser. A. The secondary emission image of immature tooth enamel. B. The characteristic X-ray image of calcium Ka from the same field as Figure A. Note amorphous lumps (arrow marks). $\times 5,000$

\section{Structures of the immature tooth enamel surface after treatment by organic solvent}

The surface structure of immature tooth enamel after treatment by $1: 2$ diaminoethane is shown in Figure 4 where it can be seen that the spheroidal substances and amorphous-shaped lumps observed in the depressions of non-treated specimens have almost disappeared; instead there are crystalline structures of enamel matrix, most of which have the appearance of well defined flakes in relief. These structures seem to correspond to the plate-like or ribbon-like crystals described by JOHANSEN and PARK (1961), Rönnholm (1962), Nylen and Scott (1963) and Travis and Glimcher (1964). The size of these flaky crystals was frequently difficult to determine because most of them were partly imbedded in the matrix. Rough estimates of their marginal length, however, show that they approximate the size of the columnar structures observed in the depressions of non-treated enamel surfaces cxccpt for some slight reduction in thickness, probably resulting from the removal of organic matrix.

Although the present pictures do not furnish any information as to the arrangement, pattern, or orientation of the flaky crystals within the depressions, general observation allows us to conclude that most of them lie parallel to the direction in which the 
rods were formed. However, a different arrangement of the flaky crystals located in the marginal ridge of the depressions was noted. Here the bulk of the bodies appeared to have been hidden within the matrix and only their exposed edges are visible. They appeared to have been stacked randomly.

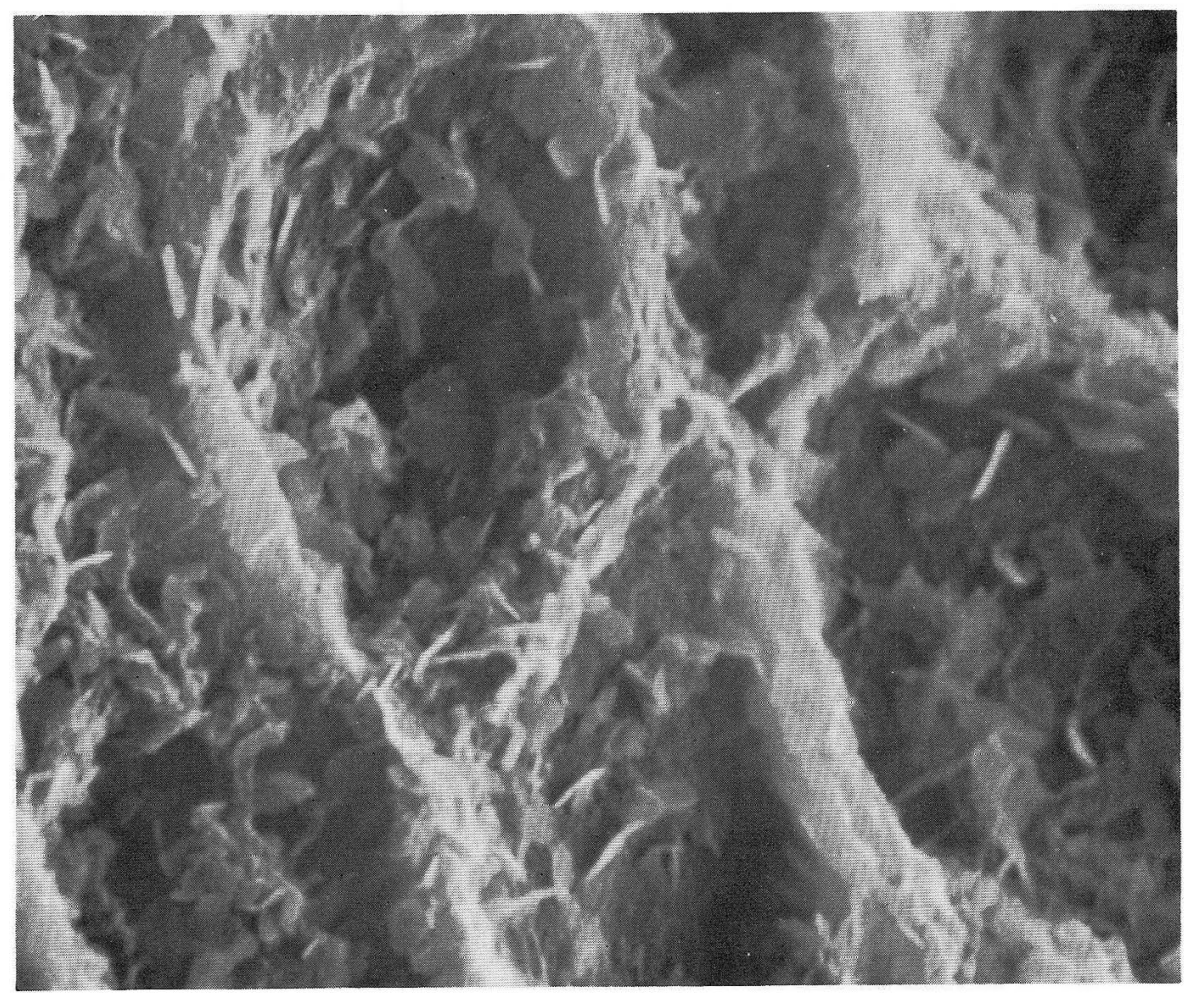

Fig. 4. The surface structures of immature tooth enamel treated with organic solvent. Note numerous flaky crystals within the depressions and on hexagonal ridges. $\times 12,000$

Although some agreement seems to have been reached as the final aspects of mature apatite crystals in the tooth enamel, divergent opinions exist about how and in what shape the inorganic crystals come to be deposited immediately following the deposition of the organic matrix and throughout their growing stages. RönNHOLM (1962) has stated that the primary form of apatite crystals apparently came into existence in an abrupt manner and, assuming either a plate-like form of certain length or a ribbon-like form, continued to grow slowly. On the other hand, Frank and NALBANDIAN (1963) have observed that apatite crystals first deposited in the organic matrix became visible as "electron dense dots" which were oriented preferentially along the axis of the enamel rod. In later stages of development, these dots grew into "electron dense thread-like units" which appeared to have been separated into groups by an amorphous substance.

We should like to add here that the columnar structures observed before treatment with the organic solvent apparently resembled the electron dense threads described by the above authors; we are of the opinion that the flake or plate forms of crystals, as 
observed by RönNHOLM and other investigators (including ourselves), might represent matured forms of the electron dense thread-like units.

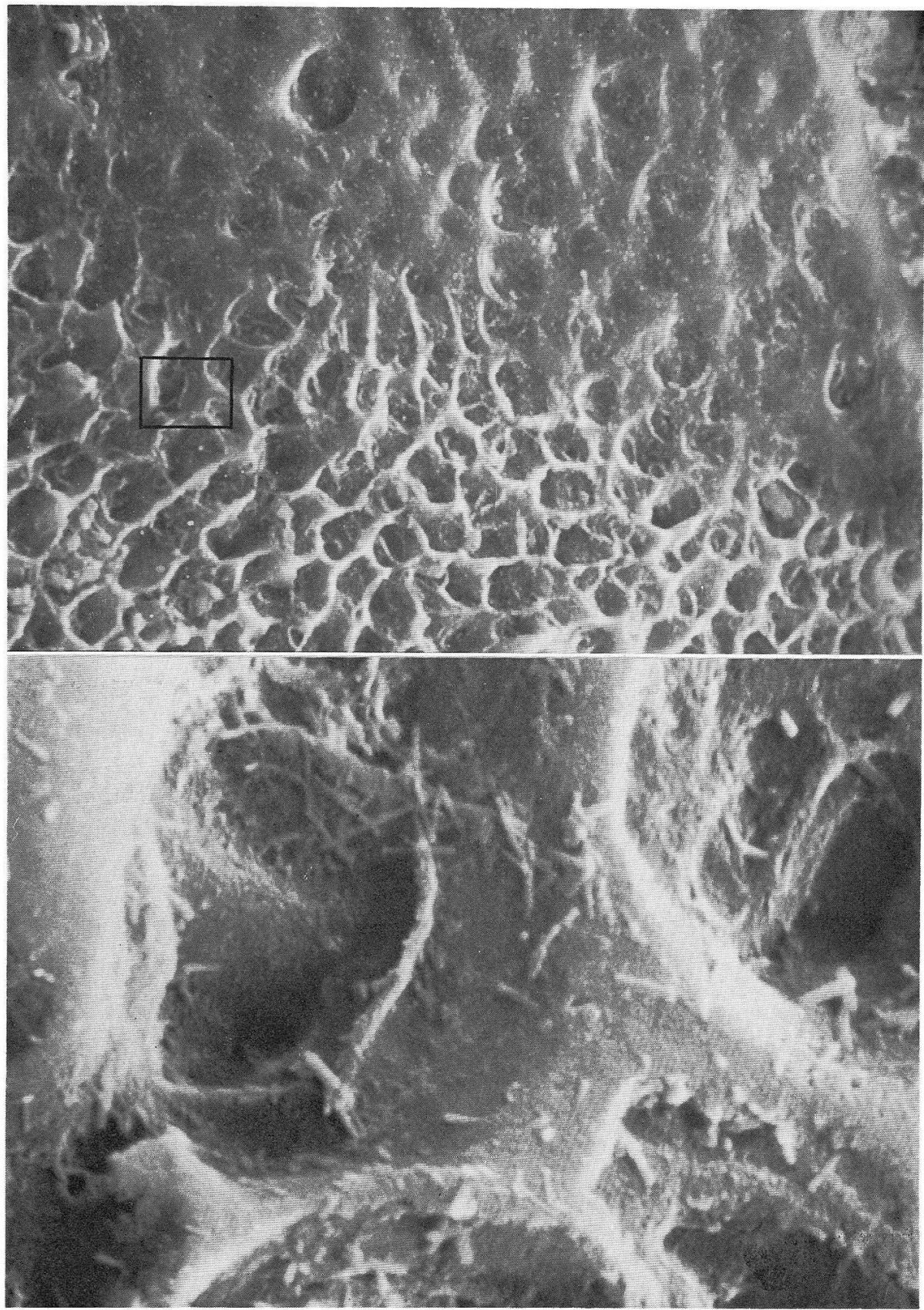

Fig. 5. The surface view of the boundary zone between immature and mature enamel. A. Shallower and more flattened floor of the depressions. $\times 1,200$. B. A closer view of the marked area of Figure A showing a horseshoe-shaped elevation of the floor. Numerous columnar structures also are seen. $\quad \times 12,000$ 


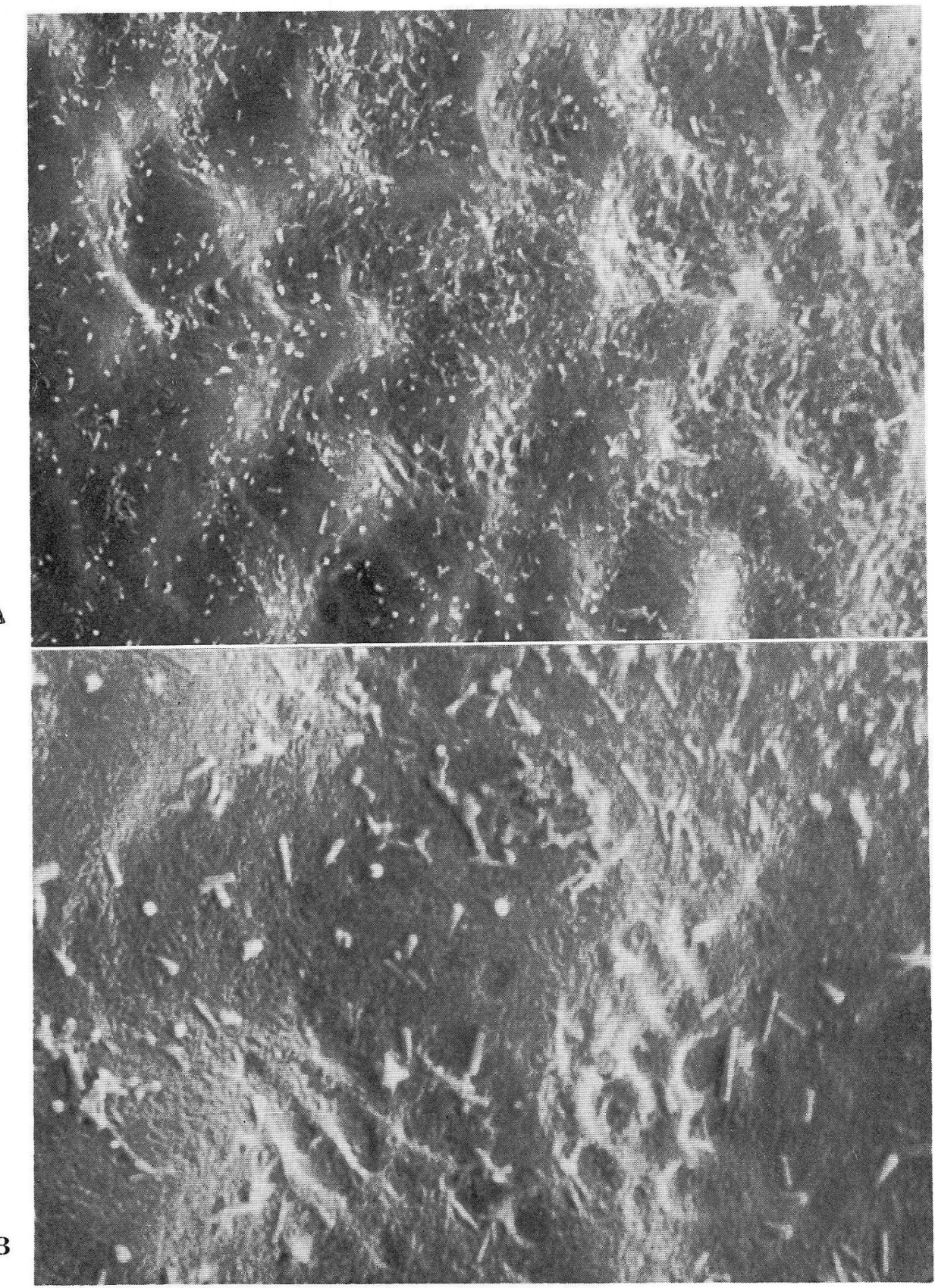

Fig. 6. The surface view of mature enamel. A. The undulation of very slight concavities and elevations arranged alternately. $\times 3,600$. B. Part of the field, at higher magnification, shown in Figure A. Numerous columnar structure as observed in the earlier stages of enamel development also are seen on the undulation. Some of the concavities are occupied by several depressions of very small size. $\times 12,000$ 


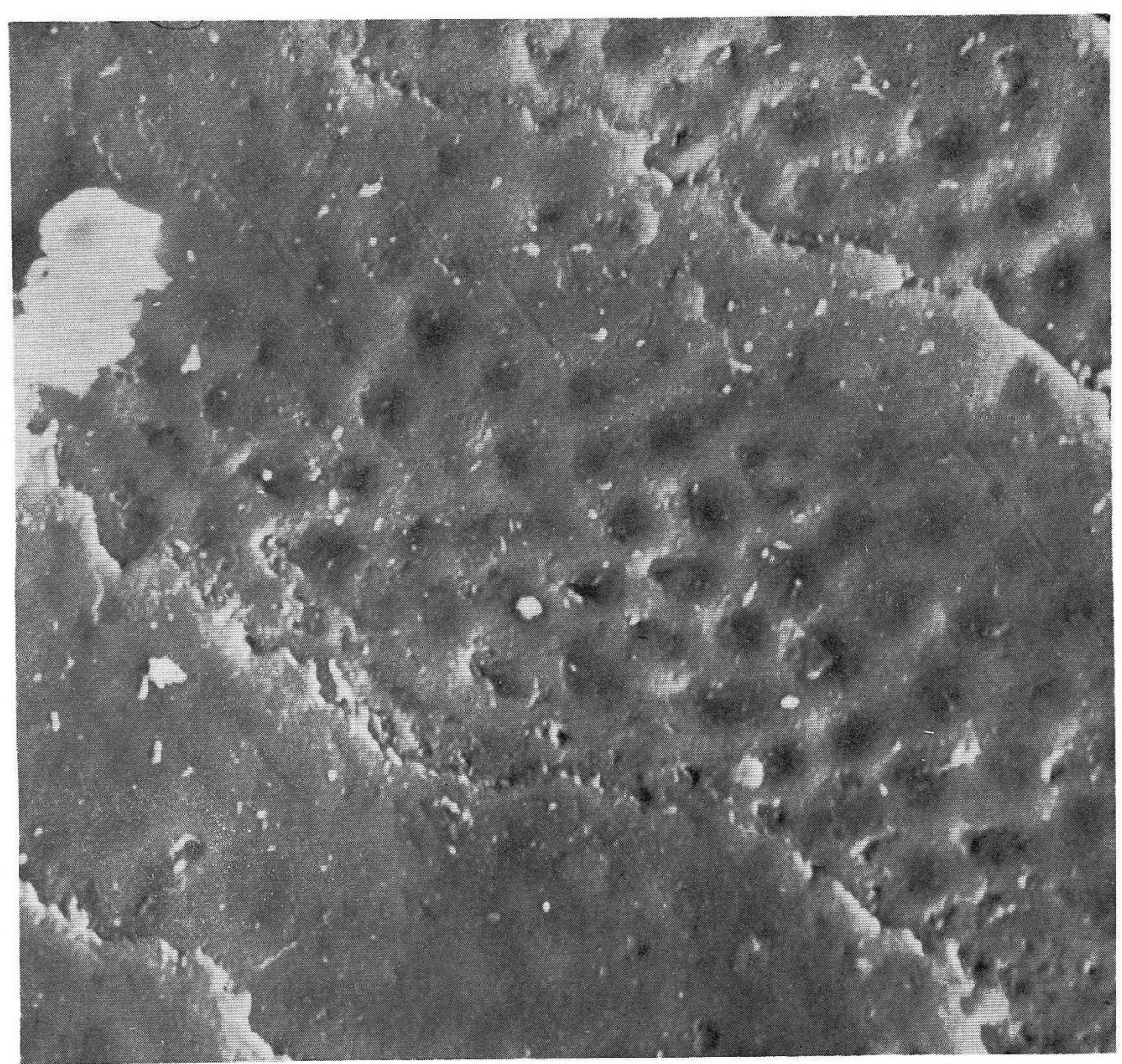

Fig. 7. The surface view of adult enamel (permanent impacted third molars) showing numerous shallower depressions on the imbrication lines of cervical portion. Compare with the undulation of deciduous mature enamel surface. $\quad \times 1,200$

\section{Surface view of the boundary zone between immature and mature enamel}

The depressions located in the zone between immature and mature enamal appeared considerably shallower and showed a more flattened floor. On the outer margin of the floor a horseshoe-shaped elevation was seen, as if it were a demarcation of the enamel rod (Fig. 5-B). It is characteristic of these depressions that there were seen hardly any structure such as a spheroidal form or amorphous lump as observed in depressions in the immature regions. Some depressions located nearer the mature enamel region were so shallow that they showed horse-shoe or arcade contours with their openings directed toward the already flattened mature enamel regions, either in cuspal or lateral directions. In less frequent instances, there were two or more depressions that were fused together in a row to form a groove (Fig. 5-A). This may be a final picture of the fusion of depressions in the immature enamal that takes place due to the lack of a bordering ridge or because of incomplete formation thereof, 


\section{Surface view of mature enamel}

Observations were conducted specifically on the surface view of the cuspal region in deciduous central incisor germs because this was the site where maturation was most complete. In this region even the shallowest depressions as observed in the boundary zone were absent. The region appeared nearly flat except that some regular undulations of very slight concavities and elevations were seen (Fig. 6-A). The depth of these concavities was generally comparable to that observed in depressions located on the imbrication lines of adult enamel surfaces (Fig. 7). Although these concavities should have pointed to the sites of individual enamel rod ends (on the basis of our observations in all other stages of earlier development of enamel), there was no definite marking of boundaries between the rod ends and the interrod substance. This was due to the absence of any sort of ridge. These concavities, like the depressions in immature enamel, had different sizes and sometimes showed an extremely shallow groove apparently produced through fusion of two or more concavities. Nevertheless, this may be regarded as the mature form of the groove as observed in the immature enamel surface. There were also found in the concavities of mature enamel some particles resembling those columnar structures which were commonly observed in depressions of the immature enamel surface. They were, however, imbedded partly in the matrix and only a marginal portion was seen.

On the floor of the concavity, there was a small area occupied by a group of several depressions of very small size (Fig. 6-B). This may be interpreted as reflecting some functional activity of the reduced ameloblasts at the final stage of enamel matrix formation, imprinted on the mineralizing front of the tooth enamel. It may be further added that despite its apparent smoothness, the surface of mature enamel was evenly coated with ultrafine particles and appeared coarse on closer observation.

\section{Summary}

Structural details of the surface of the developing deciduous tooth enamel were studied under the scanning electron microscope using materials from human fetuses ranging in age from 6 to 8 months. The excised dental germs were fixed either in $2.5 \%$ glutaraldehyde or $10 \%$ neutral formalin solution. In a number of specimens fixed, treatment by 1:2 diamino-ethane was conducted to remove organic materials from the surface of enamel.

1. The surface of developing enamel appeared to consist of a regular arrangement of depressions, each of which was concave due to the formation of the interrod portion which always preceded that of th rod ends. The size and depth of these depressions varied according to the stage of enamel development.

2. In immature stages of enamel development the depressions were always deeper than those seen in the mature enamel and showed either tapared cylindrical or wedgelike forms. The floor of the depressions were rough-surfaced, being covered by particles smaller than $100 \mathrm{~m} \mu$ in diameter. On the walls of the depressions there were numerous structures of varying size acicular to columnar in form. Many depressions also contained other structures, such as spherical granules and amorphous lumps. In the specimens treated with organic solvent these structures had almost disappeared. Instead, there 
were crystalline structures of enamel matrix, most of which had the appearance of well defined flakes in relief.

3. It was demonstrated by an electron microanalyser that the Ca concentration in the rod ends in immature stages of enamel development was much higher than that in interrod portions.

4. In the boundary zone between immature and mature enamel the depressions became considerably shallower and showed a more flattened floor.

5. The surface of mature enamel lacked even the shallowest kind of depressions as observed in the boundary zone, and there was seen only undulation of very slight concavities and elevations arranged alternately.

\section{走査型電子顕微鏡による発育乳歯エナメル質の構造（内容自抄）}

ヒトの 6 8 カ月胎児より摘出した歯胚を $2.5 \%$ グルタールアルデハイドまたは $10 \%$ 中性ホルマリン液で固定し，発育中の乳歯エナメル質の表面構造它走査型電子顕微鏡で 観察した。固定材料の一部はエナメル質表面から有機物を除くため $1: 2$ ヂアミノ エタン処理它施した。

1. 発育エナメル質表面注 小柱間質部の形成が小柱端の形成に先行することによっ て形ら゙くられた陥凹の規則的配列として見られる。陥凹の大きさ，深さはエナメル質の 発育段階によってことなる.

2. 未熟期の陥凹は より深く，先細りの円柱形あるいはクサビ形を走す．陥凹底面 は粗造で，径 $100 \mathrm{~m} \mu$ 匡どの微粒子に被われている．陥凹壁にはいろいろな長さの針状 あるい梳状の構造物が付着している. また多くの陷凹は小球状顆粒と不定形塊状物 を含えでいる. 有機溶剂処理の試料ではそれらの構造物のほとえどが消失してしまい， 代ってエナメル基質中の結晶構造が 輪郭のはっきりとした薄片様形態として浮彫りさ れて見られる.

3. 電子プローブX線マイクロアナライザーによって，未熟期の小柱端基質のカルシ ウム濃度が小柱閒質部のものよりも。かなり高いことが示された。

4. 未熟と成熟エナメル質間の境界部にある陌凹は著しく浅くなり，陌凹底もより平 坦になっている。

5. 成熟エナメル質の表面には浅い陷凹もなく，微細な起伏がみられるのみである.

\section{References}

Boyde, A.: The structure of developing mammalian dental enamel. In: (ed. by) M. V. Stack and R. W. Fearnhead: Tooth enamel. Bristol, John Wright \& Sons, 1965. (p. 163-167).

: The development of enamel structure. Proc. Roy. Soc. Med. 60: 923-928 (1967).

Fearnhead, R. W.: Electron microscopy of forming enamel. Arch. oral Biol. (Spec. suppl.) 24-48 (1961).

Frank, R. M. and J. Nalbandian: Ultrastructure of amelogenesis. In: (ed. by) A. E. W. Miles: Structural and chemical organization of teeth. New York and London, Academic press, Vol.1, 1967. (p. 339-466). 
: Comparative aspects of development of dental hard structures. J. dent. Res. 42: 422437 (1963).

Johansen, E. and H. F. Park: On the three-dimensional morphology of crystallites in developing deciduous human enamel. J. dent. Res. 40: 702 (1961).

Nylen, M. U., E. D. Eanes and K. A. Omnell: Crystal growth in rat enamel. J. Cell Biol. 18: 109-123 (1963).

Nylen, M. U. and D. B. Scott: Electron microscopic studies of odontogenesis. J. Indiana Dent. Assoc. 39: 406-421 (1960).

Reith, E. J.: Discussion of fourth session. In: (ed. by) M. V. Stack and R. W. Fearnhead: Tooth enamel, Bristol, John Wright \& Sons, 1965. (p 179).

Rönnholm, E.: The amelogenesis of human teeth as revealed by electron microscopy. 2 . The development of the enamel crystallines. J. Ultrastr. Res. 6: 249-303 (1962).

: The structure of the organic stroma of human enamel during amelogenesis. J. Ultrastr. Res. 6: 368-389 (1962).

Sognnaes, R. F., D. B. Scott, M. J. Ussing and R. W. G. Wyckoff : Electron microscopy of the enamel of teeth in various stages of development. J. dent. Res. 31: 85-93 (1952).

Travis, D. F. and Glimcher, M. J.: The structure and organization of, and the relationship between the organic matrix and the inorganic crystals of embryonic bovine enamel. J. Cell Biol. 23: 447-496 (1964). 